\title{
STUDI KINETIKA ADSORPSI ION Fe (III) MENGGUNAKAN LIMBAH AMPAS SAGU
}

\author{
Batseba Taihuttu $^{1^{*}}$, V. Kayadoe ${ }^{1}$, A. Mariwy ${ }^{1}$ \\ ${ }^{1}$ Departement of Chemistry-FKIP, Pattimura University Ambon \\ ”bacetaihuttu@gmail.com
}

Diterima 12 Agustus 2018/Disetujui 18 September 2018

\begin{abstract}
Adsorption study of the adsorption of heavy metal ions from Fe (III) using sago dregs waste was carried out. adsorption was carried out in batches, with the mass of adsorbent is $1 \mathrm{~g}$ and the concentration of Fe (III) ion is $10 \mathrm{ppm}$. in this study variations in contact time were 60,90,120,150 and 180 minutes to determine the kinetic suitable for the adsorption process of ion Fe (III) and the capacity and efficiency of sago dregs adsorption. The results showed that the adsorption of ion fe (III) using sago dregs followed pseudo second-order kinetics with R2 values that were closer to 1 that is 0,9651. adsorption of ion Fe (III) at optimum contact time of 90 minutes with adsorbent mass of $1 \mathrm{~g}$ obtained by adsorption capacity $0,3211 \mathrm{mg} / \mathrm{g}$ and the adsorption efficiency is $64,2 \%$.
\end{abstract}

Keywords: Adsorption, Sago Dregs, Fe (III) Ion, Adsorption Kinetics

\begin{abstract}
ABSTRAK
Studi kinetika adsorpsi ion logam berat Fe (III) menggunakan limbah ampas sagu telah dilakukan. Adsorpsi dilakukan secara batch, dengan massa adsoben $1 \mathrm{~g}$ dan konsentrasi ion Fe (III) $10 \mathrm{ppm}$. Pada penelitian ini dilakukan variasi waktu kontak 60, 90, 120, 150 dan 180 menit untuk mengetahui kinetika yang sesuai untuk proses adsorpsi ion Fe (III) serta kapasitas dan efisiensi adsorpsi ampas sagu. Hasil penelitian menunjukkan bahwa kinetika adsorpsi ion Fe (III) menggunakan ampas sagu mengikuti kinetika orde dua semu dengan nilai $\mathrm{R}^{2}$ yang lebih mendekati 1 yaitu 0,9651. Adsorpsi ion Fe (III) pada waktu kontak optimum 90 menit dengan massa adsorben $1 \mathrm{~g}$ diperoleh kapasitas adsorpsi 0,3211 $\mathrm{mg} / \mathrm{g}$ dan efisiensi adsorpsi 64,2\%.
\end{abstract}

Kata Kunci: Adsorpsi, Ampas Sagu, Ion Fe (III), Kinetika Adsorpsi

\section{PENDAHULUAN}

Logam berat merupakan unsur logam yang mempunyai masa jenis lebih besar dari $5 \mathrm{~g} / \mathrm{cm}^{3}$. Logam berat pada umumnya mempunyai sifat toksik dan berbahaya bagi organisme hidup, walaupun beberapa di antaranya diperlukan dalam jumlah kecil. Beberapa logam berat banyak digunakan dalam berbagai kehidupan sehari-hari. Secara langsung maupun tidak langsung toksisitas dari polutan itulah yang kemudian menjadi pemicu terjadinya pencemaran pada lingkungan sekitarnya. Apabila kadar logam berat sudah melebihi ambang batas yang ditentukan dapat membahayakan bagi kehidupan (Koestoer, 1995).

Salah satu logam berat yang sering dijumpai pencemarannya dilingkungan adalah logam $\mathrm{Fe}$. Kadar besi dalam perairan alami berkisar antara 0,05-0,2 mg/L. Pada air tanah dalam dengan kadar oksigen yang rendah, kadar besi dapat mencapai $10-100 \mathrm{mg} / \mathrm{L}$, pada air hujan mengandung besi sekitar $0,05 \mathrm{mg} / \mathrm{L}$, sedangkan pada air laut sekitar 0,01 mg/L (Effendi, 2003). Salah satu contoh 
proses pencemarannya adalah logam Fe dalam air dapat berasal dari larutnya pipa besi dalam tanah, reservoir air sari besi maupun endapan-endapan dari buangan industri sehingga dapat membahayakan manusia dan makhluk hidup lain yang mengkonsumsi air (Fajar, 2013).

Adsorpsi merupakan peristiwa terakumulasinya partikel pada permukaan. Partikel yang terakumulasi dan dijerap oleh permukaan disebut adsorbat dan material tempat terjadinya adsorpsi disebut adsorben atau substrat (Atkins, 1999). Adsorben yang sering digunakan dalam proses adsorpsi adalah alumina, karbon aktif, silika gel, abu dasar teraktivasi, zeolit, dan lainnya. Adsorben tersebut mempunyai kemampuan adsorpsi yang baik tetapi tidak ekonomis. Adsorben logam berat dari limbah hasil pertanian saat ini banyak dikembangkan. Cara ini diharapkan dapat mengurangi pembuangan limbah yang dapat menyebabkan pencemaran lingkungan serta dapat menambah nilai ekonomis limbah tersebut. Limbah pertanian yang dapat digunakan sebagai adsorben logam berat antara lain ampas sagu, ampas tebu, tongkol jagung, dan bonggol pisang (Kadirvelu et al, 2003).

Sangadji (2009), melaporkan bahwa limbah sagu memiliki kandungan bahan kering $86,4 \%$, protein kasar $2,1 \%$, lemak $1,8 \%$, serat kasar $20,3 \%$, abu $4,6 \%$, selulosa $36,3 \%$, hemiselulosa $14,6 \%$ dan lignin 9,7\%. Beberapa penelitian tentang pemanfaatan ampas sagu telah dilakukan, di antaranya asetilasi selulosa ampas sagu dan aplikasinya sebagai fase diam kromatografi kolom (Cahyani, 2010), pembuatan arang aktif dari ampas sagu sebagai adsorben logam Cu (Maheswari, 2008), dan pemanfaatan ampas sagu sebagai adsorben logam Pb dan Cu (Quek et al, 1998).

Kinetika adsorpsi menggambarkan tingkat laju penyerapan yang terjadi pada adsorben terhadap adsorbat. Karakteristik kemampuan penyerapan adsorben terhadap adsorbat dapat dilihat dari laju adsorpsinya. Laju adsorpsi dapat diketahui dari konstanta laju adsorpsi $(k)$ dan orde reaksi yang dihasilkan dari suatu model kinetika adsorpsi. Tahap pengujian laju adsorpsi dapat dilakukan dengan menduga orde reaksi (Muslich, 2010).

Studi kinetika ion logam telah banyak dilakukan oleh beberapa peneliti. Widihati, dkk. (2012), melaporkan kinetika adsorpsi ion logam $\mathrm{Cr}$ menggunakan arang batang pisang mengikuti kinetika orde dua semu. Latuihamallo (2016), melaporkan kinetika adsorpsi ion logam Fe menggunakan pasir silika mengikuti kinetika orde satu semu. Puspita dan Amaria (2013), melaporkan hasil adsorpsi logam $\mathrm{CN}^{-}$dengan menggunakan hibrida amino silika gel terimpregnasi Fe(III) mengikuti kinetika orde dua semu. Wardani dan Wulandari (2017), juga melaporkan kinetika adsorpsi logam Pb menggunakan kulit jengkol teraktivasi mengikuti kinetika orde dua semu. Pada penelitian ini akan dipelajari kinetika adsorpsi ion Fe(III) menggunakan ampas sagu.

\section{METODE PENELITIAN}

Bahan yang digunakan adalah ampas sagu, larutan $\mathrm{FeCl} 3.6 \mathrm{H} 2 \mathrm{O}$, akuades, dan kertas saring. Alat yang digunakan adalah neraca analitik, blender, ayakan 100 mesh, spatula, peralatan gelas (Pyrex), oven, megnetik stirer, stopwatch, hotplate, dan botol sampel.

\section{A. Preparasi Ampas Sagu}

Limbah ampas sagu terlebih dahulu dicuci dengan air bersih untuk menghilangkan kotoran yang masih ada. Hasil pencucian kemudian dibilas dengan menggunakan akuades dan dikeringkan menggunakan oven pada suhu $110^{\circ} \mathrm{C}$ sampai berat konstan kemudian dihitung kadar air. Ampas sagu yang telah dikeringkan kemudian dihaluskan dengan blender dan diayak menggunakan ayakan 100 mesh.

\section{B. Pembuatan Larutan Sampel Fe (III)}

Larutan sampel Fe (III) yang digunakan pada penelitian ini adalah sampel artifisial, yakni larutan $\mathrm{FeCl} 3.6 \mathrm{H} 2 \mathrm{O}$. Larutan sampel dibuat dengan menimbang 0,242 g FeCl3.6H2O kemudian dilarutkan dengan sedikit akuades. Selanjutnya dimasukkan ke dalam labu takar $100 \mathrm{~mL}$ dan diencerkan 
sampai tanda batas, diperoleh larutan sampel $500 \mathrm{ppm}$. Sampel yang digunakan untuk proses adsorpsi diperoleh dengan cara mengencerkan larutan Fe (III) 500 ppm menjadi larutan Fe (III) 10 ppm untuk variasi waktu kontak.

\section{Adsorpsi ion Fe (III) dengan Variasi Waktu kontak}

Sebanyak $1 \mathrm{~g}$ ampas sagu yang telah dihaluskan dimasukkan ke dalam $50 \mathrm{~mL}$ larutan $\mathrm{Fe}$ (III) $10 \mathrm{ppm}$. Kemudian dilakukan pengadukan dengan menggunakan magnetik stirer pada waktu 60, 90, 120, 150, dan 180 menit. Setelah tercapai waktu yang divariasikan, masing-masing campuran disaring sehingga diperoleh filtrat. Filtrat tersebut kemudian dianalisis dengan menggunakan spektrofotometer serapan atom pada panjang gelombang $248,3 \mathrm{~nm}$.

\section{Teknik Analisis Data}

Kinetika adsorpsi yang digunakan untuk mengamati proses adsorpsi ion Fe (III) menggunakan ampas sagu adalah orde satu semu, orde dua semu, model Elovich dan difusi intra-partikel. Pertama, Persamaan model kinetika orde satu semu oleh Lagergren dinyatakan sebagai berikut:

$$
\frac{\mathrm{d}}{\mathrm{d}}=\mathrm{k}_{1}\left(\mathrm{q}_{\mathrm{e}}-\mathrm{q}_{\mathrm{t}}\right)
$$

Persamaan dapat diintegrasi dengan menggunakan kondisi batas $\mathrm{qt}=0$ pada $\mathrm{t}=0$ dan $\mathrm{qt}=\mathrm{qt}$ pada $\mathrm{t}=\mathrm{t}$, sehingga persamaan menjadi:

$$
\ln \left(\mathrm{q}_{\mathrm{e}}-\mathrm{q}_{\mathrm{t}}\right)=\mathrm{q}_{\mathrm{e}}-\mathrm{k}_{1} \cdot \mathrm{t}
$$

dengan $\mathrm{q}_{\mathrm{e}}$ dan $\mathrm{q}_{\mathrm{t}}$ adalah jumlah adsorbat yang terjerap pada waktu kesetimbangan dan waktu $\mathrm{t}$ $(\mathrm{mg} / \mathrm{g}), \mathrm{k}_{1}$ tetapan laju orde satu semu $\left(\mathrm{min}^{-1}\right)$ pada proses adsorpsi. Nilai $\mathrm{q}_{\mathrm{e}}$ dan $\mathrm{k} 1$ didapat dari plot $\ln \left(q_{e}-q_{t}\right)$ versus $t$, dengan $k 1$ adalah slope dan qe adalah intersep (Danarto, 2007).

Model kinetika orde dua semu dapat dijelaskan dengan persamaan sebagai berikut:

$$
\frac{d q_{t}}{d t}=k_{2}\left(q_{e}-q_{t}\right)^{2}
$$

Parameter k2 merupakan konstanta rata-rata orde kedua. Hasil integrasi dari persamaan pada kondisi batas $q t=0$ pada $t=0$ dan $q t=q t$ pada $t=t$, adalah:

$$
\frac{\mathrm{t}}{\mathrm{q}_{\mathrm{t}}}=\frac{1}{\mathrm{k}_{\mathrm{z}} \mathrm{q}_{\mathrm{t}}^{2}}+\frac{1}{\mathrm{q}_{\mathrm{e}}} \mathrm{t}
$$

Nilai k2 dan qe dapat diperoleh dari hasil plot (t/qt) vs t (Danarto, 2007).

Model kinetik Elovich dapat digunakan untuk mempelajari laju adsorpsi berdasarkan kapasitas penjerapan pada permukaan yang heterogen dan dirumuskan dengan persamaan sebagai berikut:

$$
\frac{d \mathrm{~d}_{\mathrm{t}}}{\mathrm{d}}=\alpha \cdot \exp \left(-\beta \cdot \mathrm{q}_{\mathrm{t}}\right)
$$

Dimana $\alpha$ adalah laju awal adsorpsi $\left(\mathrm{mg} \mathrm{g}^{-1} \mathrm{~min}^{-1}\right)$ dan parameter $\beta$ berhubungan dengan luas permukaan yang tertutup dan energi aktivasi $(\mathrm{g} / \mathrm{mg})$. Setelah dilakukan integrasi dengan kondisi batas $(\mathrm{t}=0, \mathrm{qt}=0$, dan $\mathrm{t}=\mathrm{t}$, $\mathrm{qt}=\mathrm{qt})$ dan diasumsikan $\alpha \beta>\mathrm{t}$ maka persamaan menjadi:

$$
\mathrm{q}_{\mathrm{t}}=\frac{1}{\beta} \ln (\alpha \cdot \beta)+\frac{1}{\beta} \ln \mathrm{t}
$$

Jika dilakukan plot qt vs In t, maka akan diperoleh nilai $\alpha$ dan $\beta$ (Danarto, 2007). 
Model difusi intra-partikel untuk melacak perpindahan adsorbat dari permukaan adsorben ke dalam pori internal akibat pengadukan. Model ini dinyatakan dengan persamaan sebagai berikut:

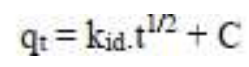

Dimana qt adalah jumlah adsorbat yang terjerap pada waktu t dan kid adalah konstanta laju difusi intra-partikel dan $\mathrm{C}$ adalah intersep. Jika dilakukan plot qt vs $\mathrm{t}^{1 / 2}$ maka akan diperoleh nilai kid dan C (Holle, 2013).

\section{HASIL PENELITIAN}

\section{A. Preparasi Ampas Sagu}

Preparasi ampas sagu diawali dengan pencucian dengan air bersih dan dibilas dengan akuades yang bertujuan untuk menghilangkan kotoran-kotoran yang masih tersisa dari lokasi pengambilan sampel. Sampel kemudian dikeringkan sampai berat konstan pada suhu $110^{\circ} \mathrm{C}$ untuk menghilangkan air sehingga memudahkan proses penghalusan sampel. Kadar air dalam ampas sagu sebesar $34,05 \%$. Proses preparasi sampel dilanjutkan dengan penghalusan sampel menggunakan blender dan diayak menggunakan ayakan 100 mesh. Proses ini bertujuan untuk memperkecil dan menghomogenkan ukuran partikel ampas sagu sehingga dapat memaksimalkan proses penyerapan (Syauqiah, 2011).

Bonenfant dkk (2008) mengemukakan bahwa ukuran partikel menjadi salah satu faktor penting yang mempengaruhi kapasitas adsorpsi. Semakin kecil ukuran partikel, maka luas permukaan akan semakin besar sehingga adsorbat yang terserap akan semakin banyak.

\section{B. Adsorpsi lon Fe (III) Menggunakan Ampas Sagu dengan Variasi Waktu Kontak}

Waktu kontak optimum merupakan waktu di mana tercapainya titik kesetimbangan antar zat terlarut yang teradsorpsi dengan larutan yang masih ada. Penentuan waktu kontak optimum dilakukan dengan mengadsorpsi $50 \mathrm{~mL}$ ion logam Fe (III) 10 ppm yang ditambahkan ke dalam $1 \mathrm{~g}$ ampas sagu. Proses pengadukan dilakukan dengan menggunakan magnetik stirer untuk setiap variasi waktu kontak 60, 90, 120, 150, dan 180 menit dengan kecepatan konstan. Setelah tercapainya waktu yang divariaskan pada proses adsorpsi, campuran disaring dengan menggunakan kertas saring kemudian filtrat dianalisis absorbansinya pada panjang gelombang $248,3 \mathrm{~nm}$. Konsentrasi ion $\mathrm{Fe}$ (III) setelah adsorpsi dan kapasitas adsorpsi ion Fe (III) menggunakan pasir silika ditunjukkan pada Tabel 1.

Tabel 1. Kapasitas adosrpsi ion Fe (III) menggunakan ampas sagu

\begin{tabular}{ccc}
\hline $\begin{array}{c}\text { Waktu } \\
\text { kontak } \\
\text { (menit) }\end{array}$ & $\begin{array}{c}\text { Konsentrasi Fe } \\
\text { (III) setelah } \\
\text { adsorpsi (ppm) }\end{array}$ & $\begin{array}{c}\text { Kapasitas } \\
\text { adsorpsi } \\
\text { (mg/g) }\end{array}$ \\
\hline 60 & 4,7775 & 0,2612 \\
90 & 3,5787 & 0,3211 \\
120 & 4,5845 & 0,2708 \\
150 & 3,8084 & 0,3096 \\
180 & 4,4066 & 0,2797 \\
\hline
\end{tabular}




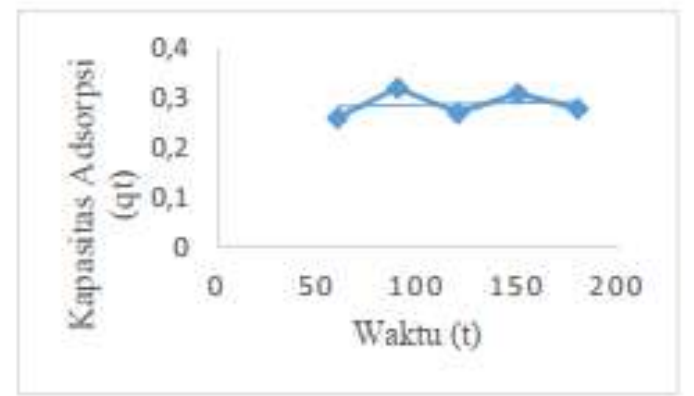

Gambar 1. Grafik Hubungan Kapasitas Adsorpsi Ampas Sagu terhadap Waktu Kontak

Berdasarkan grafik dapat dilihat bahwa kapasitas adsorpsi dari adsorben ampas sagu terhadap ion logam $\mathrm{Fe}$ (III) secara umum mengalami peningkatan diawal adsorpsi seiring dengan bertambahnya waktu interaksi. Hal ini disebabkan oleh interaksi antara sisi aktif dari selulosa yaitu gugus hidroksil $(-\mathrm{OH})$ dengan ion Fe (III) sehingga memungkinkan ion Fe (III) untuk terus teradsorpsi sampai mencapai waktu kesetimbangan. Hal tersebut berlangsung dari selang waktu 60-90 menit. Namun, pada menit ke 120 terjadi penurunan kapasitas adsorpsi, sedangkan pada menit 150 kembali terjadi peningkatan dan pada menit ke 180 terjadi penurunan kapasitas adsorpsi. Dengan kata lain, pada variasi waktu kontak 120-180 menit terjadi kompetisi adsorpsi dan desorpsi pada permukaan adsorben. Pada kondisi ini, semua sisi aktif adsorben sudah jenuh sehingga kemampuan adsorpsi mengalami penurunan. Hal ini disebabkan oleh ikatan antara ion Fe (III) dengan sisi aktif ampas sagu menjadi lemah sehingga ion Fe (III) yang telah terikat pada sisi aktif mudah terlepas kembali kedalam larutannya. Semakin lama waktu kontak antara ion Fe (III) dengan ampas sagu memungkinkan terjadinya peningkatan penyerapan ion logam, namun jika terlalu lama dapat menurunkan tingkat penyerapan. Hal ini disebabkan karena semakin lama waktu kontak dapat mengakibatkan desorpsi, yaitu lepasnya ion logam Fe yang sudah terikat pada gugus fungsi hidroksil $(-\mathrm{OH})$ dari adsorben (Fatimah, 2014). Dengan demikian dapat diketahui bahwa waktu kontak optimum pada proses adsorpsi ion logam Fe (III) dengan menggunakan ampas sagu adalah pada menit ke 90 dengan kapasitas adsorpsi sebesar $0,3211 \mathrm{mg} / \mathrm{g}$.

\section{Kinetika Adsorpsi}

Kinetika adsorpsi digunakan untuk mengetahui laju penyerapan yang terjadi pada adsorben terhadap adsorbat dan dipengaruhi oleh waktu. Waktu kontak yang diperlukan untuk mencapai kesetimbangan adsorpsi dijadikan sebagai ukuran laju adsorpsi (Haryanto, 2014). Model kinetika adsorpsi yang digunakan dalam penelitian ini adalah kinetika adsorpsi orde satu semu, orde dua semu, Elovich, dan difusi intra-partikel.

Data penentuan kinetika adsorpsi ditunjukkan pada Tabel 2 dan 3. 
Tabel 2. Data penentuan kinetika orde satu dan dua semu berdasarkan persamaan kinetika orde satu dan dua semu

\begin{tabular}{ccc}
\hline \multirow{2}{*}{$\begin{array}{c}\text { Waktu Kontak } \\
\text { (menit) }\end{array}$} & $\begin{array}{c}\text { Orde Satu } \\
\text { Semu }\end{array}$ & $\begin{array}{c}\text { Orde Dua } \\
\text { Semu }\end{array}$ \\
\cline { 2 - 3 } & $\ln (q e-q t)$ & $t / q t$ \\
\hline 60 & $-2,76161$ & 41,58869 \\
90 & $-4,06692$ & 104,70839 \\
120 & $-3,34076$ & 186,40719 \\
150 & $-4,50714$ & 239,22627 \\
180 & $-4,84597$ & 304,28021 \\
\hline
\end{tabular}

Tabel 3. Data penentuan kinetika Elovich dan difusi intra-partikel berdasarkan persamaan Elovich dan difusi intra-partikel

\begin{tabular}{cccc}
\hline & & & \\
\multirow{2}{*}{$\begin{array}{c}\text { Waktu kontak } \\
\text { (menit) }\end{array}$} & $\begin{array}{c}\mathrm{qt} \\
(\mathrm{mg} / \mathrm{g})\end{array}$ & Elovich & Difusi intra-partikel \\
\cline { 3 - 4 } & & In t/qt & $\mathrm{t} 1 / 2$ \\
\hline 60 & 0,2612 & 4,0943 & 7,7459 \\
90 & 0,3211 & 4,4998 & 9,4868 \\
120 & 0,2708 & 4,7875 & 10,9544 \\
150 & 0,3096 & 5,0106 & 12,2474 \\
180 & 0,2797 & 5,1929 & 13,4164 \\
\hline
\end{tabular}

Penentuan model adsorpsi ini didasarkan pada koefisien determinasi $\left(R^{2}\right)$ dan kapasitas adsorpsi. Model kinetika adsorpsi ditentukan dengan mengolah data penentuan waktu optimum. Hasil ini ditunjukkan pada Gambar 3.

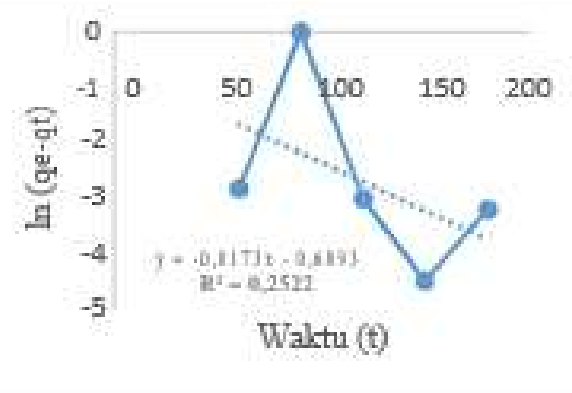

(a)

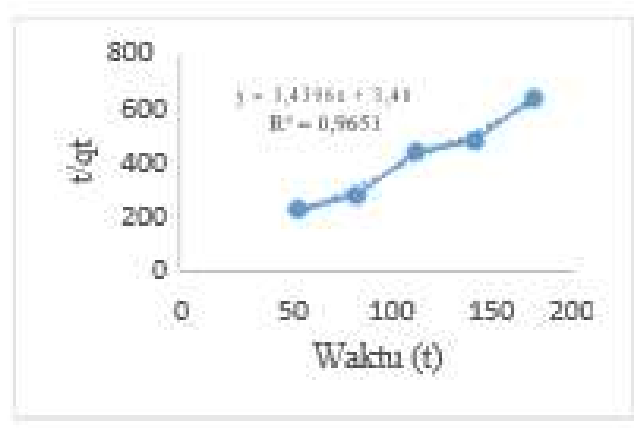

(b) 


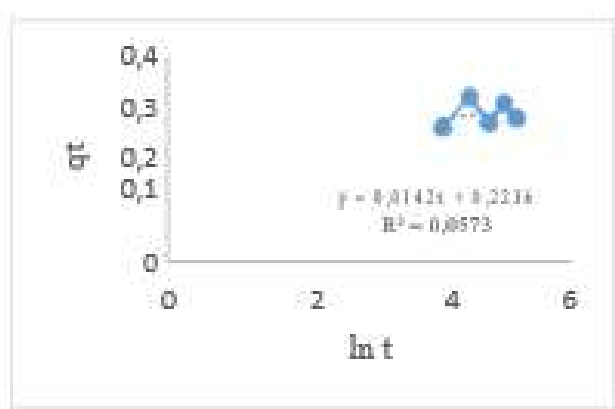

(c)

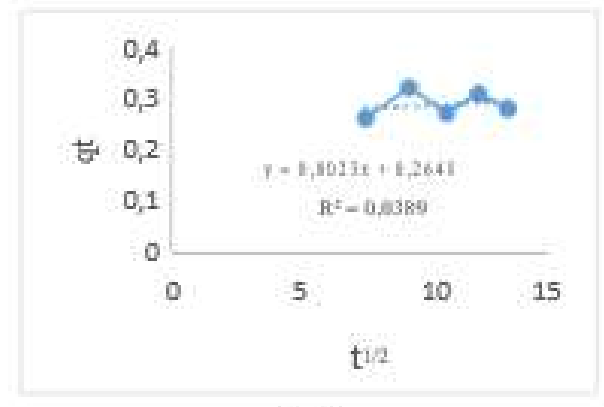

(d)

Gambar 2. (a) Grafik kinetika orde satu semu (b) Grafik kinetika orde dua semu (c) Grafik kinetika Elovich (d) Grafik kinetika difusi intra-partikel

Berdasarkan grafik pada Gambar 4.3, dapat diketahui bahwa kinetika orde dua semu menghasilkan nilai koefeisien determinasi $\left(R^{2}\right)$ yang mendekati 1 yaitu 0,9651 . Nilai $R^{2}$ yang mendekati 1 menunjukkan bahwa grafik kinetika orde dua semu lebih linear dari grafik kinetika orde satu semu, kinetika Elovich, dan kinetika difusi intra-partikel.

Dengan demikian dapat diketahui bahwa adsorpsi ion Fe (III) menggunakan ampas sagu mengikuti kinetika orde dua semu. Model kinetika ini sama dengan yang dilaporkan Nafsiyah, dkk (2017), di mana proses adsorpsi ion Fe (III) menggunakan bentonit teraktivasi asam sulfat mengikuti kinetika orde dua semu. Kinetika orde dua semu mengasumsikan bahwa adsorpsi yang terjadi antara ampas sagu dengan ion Fe (III) adalah adsorpsi kimia, yakni terjadi pembentukan ikatan kimia antara molekul adsorbat dengan permukaan adsorben. Adsorpsi kimia melibatkan ikatan koordinasi sebagai hasil penggunaan bersama pasangan elektron oleh adsorbat dan adsorben, di mana gugus $-\mathrm{OH}$ bertindak sebagai ligan karena memiliki pasangan elektron bebas yang akan berikatan dengan ion Fe (III) membentuk ikatan kompleks melalui ikatan kovalen (Mandasari dan Purnomo, 2016). Reaksi yang terjadi pada proses adsorpsi $\mathrm{Fe}^{3+}$ dengan selulosa ditunjukkan pada Gambar 3.

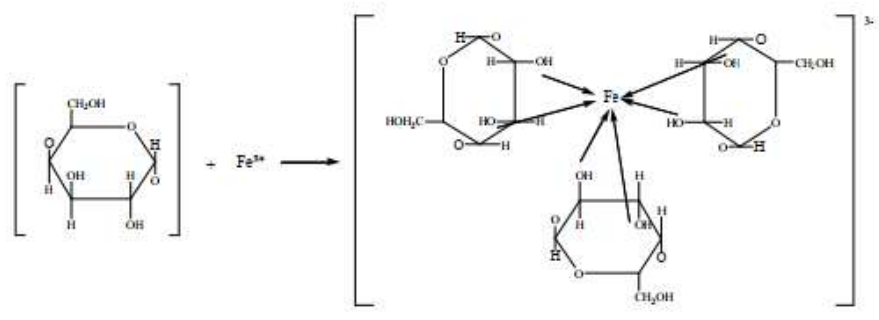

Gambar 3. Reaksi selulosa dengan ion Fe (III) (Udin, 2015)

Udin (2015) telah melakukan penelitian tentang adsorpsi ion $\mathrm{Cd}^{2+}$ dengan menggunakan serat sabut kelapa hijau. Hasil penelitian menunjukkan bahwa mekanisme yang terjadi antara selulosa pada serabut kelapa hijau dengan ion $\mathrm{Cd}^{2+}$ adalah mekanisme pembentukan kompleks. Hal ini juga diperkirakan terjadi pada ion $\mathrm{Fe}^{3+}$ dengan selulosa pada ampas sagu. Di mana pasangan elektron bebas dari atom $\mathrm{O}$ pada gugus hidroksil digunakan bersama untuk berikatan dengan ion $\mathrm{Fe}^{3+}$ membentuk senyawa kompleks melalui ikatan kovalen koordinasi. 


\section{KESIMPULAN}

Berdasarkan hasil penelitian, dapat disimpulkan bahwa:

1. Kapasitas adsorpsi dan efisiensi adsorpsi ampas sagu terhadap ion logam Fe (III) yaitu 0,3211 $\mathrm{mg} / \mathrm{g}$ pada waktu kontak optimum 90 menit.

2. Kinetika adsorpsi yang sesuai untuk adsorpsi ion logam Fe (III) oleh ampas sagu adalah kinetika orde dua semu.

\section{DAFTAR PUSTAKA}

Atkins, P.W. 1997. Kimia Fisik. Jilid 2. Edisi keempat. (Terjemahan Irma I. Kartohadiprodjo). Jakarta: Erlangga.

Bonenfant, D., Kharoune, M., Niquette, P., Mimeault, M., and Hausler, R. 2008. Advances in Principal Factors Influencing Carbon Dioxide Adsorption on Zeolite. Science and Technology of Advanced Materials. 9(2): 1-7.

Cahyani, R.D. 2010. Asetilasi selulosa ampas sagu dan aplikasinya sebagai fase diam kromatografi kolom. Skripsi. Bogor: Institut Pertanian Bogor.

Fajar, M., Zul Alfian., \& Harry Agusnar. 2013. Penentuan Kadar Unsur Besi, Kromium, dan Aluminium dalam Air Baku dan pada Pengolahan Air Bersih di Tanjung Gading dengan Metode Spektrofotometri Serapan Atom. Departemen Kimia FMIPA USU. Jurnal Saintica Kimia. 1(2): 23-26.

Fatimah, N., Prasetya A.T., \& Sumarni, W. 2014. Penggunaan Silika Gel Terimobilisasi Biomassa Aspergillus Niger untuk Adsorpsi Ion Logam Fe (III). Indonesian Journal of Chemical Science. 3(3): 183-187.

Haryanto, B., Firmanto, P., Herman, H., Rifai, R., Muhammad, R. 2014. Kajian Kemampuan Adsorpsi Batang Jagung (Zea Mays.) Terhadap Ion Logam Kadmium $\left(\mathrm{Cd}^{2+}\right)$. Jurnal Teknologi Pertanian Andalas. 20(1): 59-68

Holle, R.B., Wuntu, A.D., Sangi, M.S. 2013. Kinetika Adsorpsi Gas Benzena pada Karbon Aktif Tempurung Kelapa. Jurnal Mipa Unsrat. 2(2): 100-104.

Kadirvelu, K., Kavipriya, M., Karthika, C., Radhika, M., Vennilamani, N., Pattabhi, S. 2003. Utilization of Various Agricultural Wastes for Activated Carbon Preparation and Application for The Removal of Dyes and Metals Ions from Aqueous Solutions. Biosource Technology 87:129132.

Koester, Y. 1995. Kimia dan Ekotoksikologi Pencemaran. Terjemahan dari Chemistry and Ecotoxicology of Pollution oleh D.W. Connel. Jakarta: UI Press.

Latuihamallo, M.R. 2016. Adsorpsi Ion Fe (III) Menggunakan Pasir Silika. Skripsi. Universitas Pattimura. Ambon.

Maheswari, P., Venilamani, N., Madhavakrishnan, S., Shabudeen, S., Venckatesh, R., Pattabhi, S. 2008. Utilization of sago waste as an adsorbent for the removal of $\mathrm{Cu}(\mathrm{II})$ ion from aqueous solution. Chemistry 5:233-242.

Mandasari, I., dan Purnomo, A. 2016. Penurunan Ion Besi (Fe) dan Mangan (Mn) dalam Air dengan Serbuk Gergaji Kayu Kamper. Jurnal teknik ITS. 5(1): 11-16.

Muslich, S.P., dan Hayuningtyas, I. 2010. Studi Kinetika Adsorpsi $\beta$-Karoten dari Minyak Kelapa Sawit Mentah Menggunakan Bentonit. Jurnal Teknik Industri Pertanian. 19(2): 93-100.

Nafsiyah, N., Shofiyani, A., Syahbanu I. 2017. Studi Kinetika dan Isoterm Adsorpsi Fe(III) pada Bentonit Teraktivasi Asam Sulfat. JKK. 6(1): 57-63.

Puspita, N., dan Amaria. 2013. Kinetika Adsorpsi Ion Sianida ( $\mathrm{CN}^{-}$) oleh Hibrida Amino Silika Gel

Terimpregnasi Fe (III). Jurnal Kimia. 2(3): 148-155. 
Quek, S.Y., Wase, D.A.J., Forster, C.F. 1998. The use of sago waste for thes of lead and copper. Water SA 24:251-256.

Syauqiah, I., Amalia, M., Kartini, H.A. 2011. Analisis Variasi Waktu dan Kecepatan Pengadukan pada Proses Adsorpsi Limbah Logam Berat dengan Arang Aktif. Info Teknik. 12(1): 11-20.

Udin, Y. 2015. Biosorpsi Kadmium (Cd) pada Serat Sabut Kelapa Hijau (Cocos nucifera) Teraktivasi Natrium Hidroksida $(\mathrm{NaOH})$. Skripsi. UINA, Makassar.

Wardani, G.A., dan Wulandari, W.T. 2017. Studi Kinetika dan Isoterm Adsorpsi Timbal (II) pada Kulit Jengkol (Pithecellobium jiringa) Teraktivasi. Kovalen. 3(3): 252-257.

Widihati, I.A.G., Ni, G.A.M., Dwi Adhi., Nirmalasari, Y. 2012. Studi Kinetika Adsorpsi Larutan lon Logam Kromium (Kr) Menggunakan Arang Batang Pisang (Musa paradisiaca). Jurnal Kimia. 6(1): 8-16 